\title{
Diphyllobotbrium latum infection in a non-endemic country: case report
}

\author{
Infecção pelo Diphyllobothrium latum em país \\ não endêmico: relato de caso
}

\author{
Mauricio M. Llaguno ${ }^{1}$, Juan Cortez-Escalante ${ }^{1}$, Jitra Waikagul ${ }^{2}$, \\ Ana Carolina Guimarães Faleiros ${ }^{3}$, Francisco das Chagas ${ }^{1}$ and Cleudson Castro ${ }^{1}$
}

\begin{abstract}
Diphyllobothriasis, which is rarely described in Brazil, was reported initially as a travelers' disease and as an accidental infection in individuals who ate raw freshwater fish. This report aims to present the case of a 20-year-old patient with confirmed Diphyllobothrium latum infection.
\end{abstract}

Key-words: Diphyllobothriasis. Diphyllobothrium latum. Emerging disease.

\section{RESUMO}

A difilobotríase, raramente descrita no Brasil, foi referida inicialmente como doença de viajantes e como infecção acidental em indivíduos que se alimentam com peixe cru de água doce. Este relato objetiva apresentar o caso de uma paciente de 20 anos com infecção confirmada pelo Diphyllobothrium latum.

Palavras-chaves: Difilobotríase. Diphyllobothrium latum. Doença emergente.

Diphyllobothriasis is an ichthyic zoonosis accidentally acquired by humans ${ }^{711}$, with worldwide distribution and sporadic outbreaks. Cases in South America are restricted to Chile, Peru, Argentina and Brazil ${ }^{6} 10$

Humans become infected by ingesting larvae (plerocercoids) in raw or poorly cooked freshwater fish. Several species of diphyllobothriids have been reported in humans:Diphyllobothrium latum, Diphyllobothrium pacificum and Diphyllobothrium nibonkaiense have been commonly associated with human cases, generally infecting the small intestine ${ }^{912}$.

Most infections are asymptomatic. However, some cases have been associated with megaloblastic anemia, gastrointestinal discomfort, anorexia, nausea, vomiting, asthenia, weight loss, eosinophilia and diarrhea. Occasionally, infection may cause acute abdominal pain and intestinal obstruction. In rare circumstances, migration of proglottids can cause cholangitis or cholecystitis ${ }^{8}$. The associated symptomatology is non-specific, but megaloblastic anemia is a well-described common complication in Scandinavian patients.

The first cases of diphyllobothriasis in Brazil were observed by Pirajá da Silva in Bahia in 1915, in a Scandinavian sailor, and by Samuel Pessoa in São Paulo, in a French woman who lived in Switzerland ${ }^{26}$. After a long gap, several cases were diagnosed in 2004 , in patients who had the habit of eating sushi and sashimi containing raw fish ${ }^{5}$. This paper presents an autochthonous case of Diphyllobothrium latum infection in Brasília, Federal District, Brazil.

\section{CASE REPORT}

A 20-year-old woman living in Brasília presented to the outpatient service of the University Hospital of Brasilia (HUB), in 2006, after intestinal expulsion of a large white-ribbon parasite and the use of large amounts of mebendazole (200mg bid for 4 days) and praziquantel (600mg tid for 3 days). At her consultation with the physician, she reported that she had been suffering from gastrointestinal disorders such as abdominal cramps, flatulence, sporadic diarrhea, polyphagia and other unspecific symptoms like intense general itching and irritability for the preceding two years. She revealed that she often ate smoked meat products like pork and bacon and that she ate raw fish in sushi and sashimi in three local Japanese restaurants, twice a week. She had a family

1. Núcleo de Medicina Tropical, Universidade de Brasília, Brasília, DF. 2. Mahidol University, Bangkok, Thaliand. 3. Curso de Pós-Graduação em Medicina Tropical, Universidade Federal do Triângulo Mineiro, Uberaba, MG.

Address to: Dr. Cleudson Castro. Núcleo de Medicina Tropical/UnB. Caixa Postal 04-671, 70919-970 Brasília, DF.

Fax: $55613273-2811$

e-mail: tropical@unb.br

Recebido para publicação em: 24/01/2008

Aceito em: 05/06/2008 
history of cysticercosis and taeniasis without ever having received treatment.

Her laboratory test results did not show any remarkable abnormalities: RBC 4.7 x 10\% $/ \mu \mathrm{l}$, hemoglobin $13.7 \mathrm{~g} / \mathrm{dl}$, hematocrit $42 \%$, WBC $8.6 \times 10^{3} / \mu \mathrm{l}$, platelets $316 \times 10^{3} / \mu \mathrm{l}$, MCV $88.2 \mathrm{fl}, \mathrm{MCH}$ $28.8 \mathrm{pg}$ and eosinophil count $6 \%$.

The morphology and histology of the parasite were investigated. The adult worm appeared to be segmented without a scolex and it was $38 \mathrm{~cm}$ in length, with a total count of 114 proglottids, each measuring approximately $0.80 \mathrm{~mm}$ in width by $0.29 \mathrm{~mm}$ in length (Figure 1A). The mature and gravid proglottids were broader than their length, with a typical rosette-shaped uterus (Figure 1B). A longitudinal histological section (Figure 1C) showed the cirrus sac (1), ovaries (2), vitellaria (3) and seminal sac (4). The eggs (Figure 1D) measured $64 \pm 5 \mu \mathrm{m}$ by $43 \pm 3 \mu \mathrm{m}$, and had an operculum (a), a knob (b) and a moderately thick shell. From these characteristics, the parasite matched with Diphyllobothrium latum.

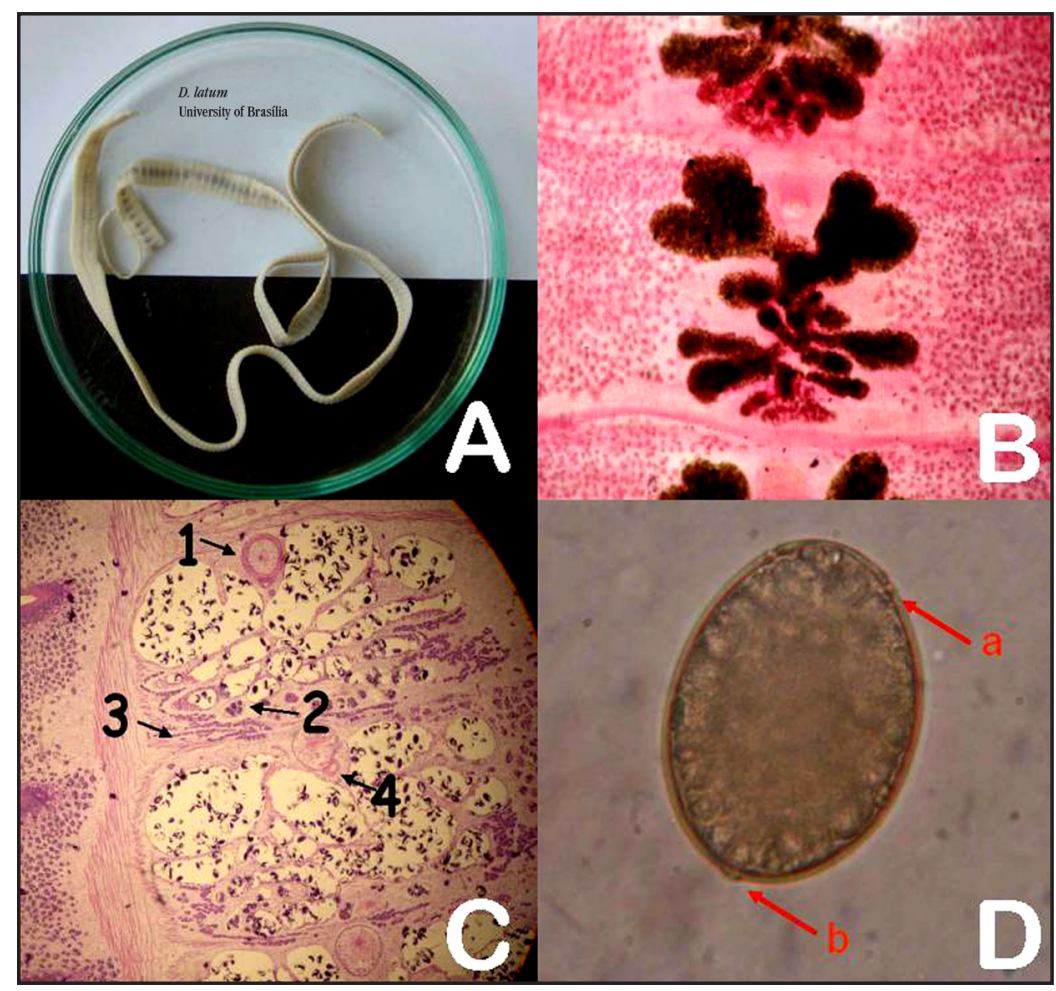

Figure 1 - A: adult worm. B: typical rosette-shaped uterus. C: histological section showing: 1. cirrus sac, 2. ovaries, 3. vitellaria, 4. seminal sac. D: egg showing: a. operculum, b. knob.

\section{DISCUSSION}

This was an autochthonous case of Diphyllobothrium latum. The previous outbreaks in Brazil occurred at the end of 2004 and in the first quarter of 2005. This suggests that diphyllobothriasis is expanding, but that the sources of the fish are not still clear. Twenty-three cases of diphyllobothriasis were reported as a result of laboratory detection of eggs or proglottids of Diphyllobothrium latum during this period ${ }^{5}$.

Finding an operculated egg with a small knob on the antioperculum side is the most accurate diagnostic characteristic for identifying diphyllobothriids. However, the size of their eggs varies from one species of Diphyllobothrium to another ${ }^{3}$. According to some reports, the eggs of Diphyllobothrium pacificum are 40-60 $\mu \mathrm{m}$ in length and $36-40 \mu \mathrm{m}$ in width ${ }^{1}$, while the egg size of Diphyllobothrium latum is approximately $58-76$ by $40-51 \mu \mathrm{m}^{4}$.

Some authors have supported the hypothesis that fish may be the source of Diphyllobothrium latum plerocercoid infection.
Another possibility is that the life cycle of Diphyllobothrium latum may have become established along the Brazilian coast and in the country's rivers ${ }^{9}$.

Epidemiological investigations are being conducted in São Paulo to identify the source of Diphyllobothrium latum plerocercoids. These may help towards implementing educational and sanitary measures aimed at preventing diphyllobothriasis from becoming endemic in Brazil5.

Diphyllobothriasis is becoming an emerging disease in Brazil, due probably to the expansion in the habit of eating raw or partially cooked fish.

\section{REFERENCES}

1. Baer JG, Miranda H, Fernandes W, Medina J. Human diphyllobothriasis in Peru. Zeitschrift fur Parasitenkunde 28: 277-289, 1967.

2. Coutinho E. Tratado de clínica das doenças infectuosas, parasitárias e peçonhentas, $6^{a}$ edição, Editora Guanabara Koogan, Rio de Janeiro, p. $638,1957$. 
3. Chou HF, Yen CM, Liang WC, Jong YJ. Diphyllobothriasis latum: the first child case report in Taiwan. Kaohsiung Journal of Medical Sciences 22: 346-351, 2006.

4. Dick TA, Nelson PA, Choudhury A. Diphyllobothriasis: update on human cases, foci, patterns and sources of human infections and future considerations. Southeast Asian Journal of Tropical Medicine Public Health 32: 59-76, 2001.

5. Eduardo MBP, Sampaio JLM, Gonçalves EMN, Castilho VLP, Randi AP, Thiago C, Pimentel EP, Pavanelli E, Colleone RP, Vigilato MAN, Marsiglia DAP, Atui MB, Torres DMAGV. Diphyllobothrium spp: um parasita emergente em São Paulo associado ao consumo de peixe cru - sushis e sashimis. Boletim Epidemiológico Paulista 2: 1-5, 2005.

6. Emmel VE, Inamine E, Secchi C, Brodt TC, Amaro MC, Cantarelli VV, Spalding S. Diphyllobothrium latum: relato de caso no Brasil. Revista da Sociedade Brasileira de Medicina Tropical 39: 82-84, 2006.

7. Ko RC. Fish borne parasitic zoonoses. In: Woo PTK (ed) Fish diseases and disorders. Protozoan metazoan infections, CAB International, London, Volume 1. p. 631-671, 1995.
8. Rohela M, Jamaiah I, Chan KW, Yusoff WS. Diphyllobothriasis: the first case report from Malaysia. Southeast Asian Journal of Tropical Medicine and Public Health 33: 229-230, 2002.

9. Sampaio JLM, Andrade VP, Lucas MC, Fung L, Gagliardi SMB, Santos SRP Diphyllobothriasis, Brazil. Emerging Infectious Diseases. Available from http:// www.cdc.gov/ncidod/EID/vol11no10/05-0377.htm, 2005.

10. Santos FLN, Faro LB. The first confirmed case of Diphyllobothrium latum in Brazil. Memórias do Instituto 0swaldo Cruz 100: 585 -586, 2005.

11. Semenas L, Kreiter A, Urbanski J. New cases of human diphyllobothriasis in Patagonia, Argentina. Revista de Saúde Pública 35: 214 -216, 2001.

12. Yamane Y, Shiwaku K, Fukushima T, Isobe A, Yonevama T, Gao TQ, Wang CJ. The recent situation of diphyllobothriasis in Japan: Epidemiology, taxonomy and clinical features. Proceedings of 2nd Japan-Korea Parasitologist Seminar (Forum Cheju 2) 2: 74 -78, 1996. 